\title{
A Literature Review: Women's Equality in the E- Commerce Information Technology Industry in the Digital Age in Developing Countries
}

\author{
${ }^{1}$ Faiz, ${ }^{2}$ Tara Boyhan, ${ }^{3}$ Wilma Cordelia Izaak, ${ }^{4}$ Indrawati Yuhertiana and ${ }^{5}$ Tri Kartika \\ (wilma.izaak.mnj@upnjatim.ac.id ${ }^{3}$ ) \\ ${ }^{1}$ Magister Management Department, Universitas Pembangunan Nasional "Veteran" Jawa Timur \\ ${ }^{2}$ Health Management, University of Notre Dame \\ 3,4 Management Department, Universitas Pembangunan Nasional "Veteran" Jawa Timur \\ ${ }^{5}$ Accounting Department, Universitas Pembangunan Nasional "Veteran" Jawa Timur
}

\begin{abstract}
This paper is a literature review of Women Equality in Information Technology Insdustry E-Commerce on A Developing Country. The purpose of this literature review gets the visualitation of Indonesia's e-commerce situation, how far the level women equality in it and equality factors. Articles and journal were collected by using a scholar search engine national and international. Other data like statitic, rank were collected by using meta-search engine, national government's website, international forum, and private sector website. The resulst shows that Indonesia's women equality in e-commerce industry still in the medium to low level. There are three issues, psychic, gender discrimination and work-life balance. Then, there are two perspectives of women in e-commerce, seller and buyer, both of them are powerful
\end{abstract}

Keywords: Gender Diversity; E-Commerce; Women's Equality; Gender's Equality.

\section{Introduction}

Nowadays the society is in an era where everything is fast, automatic, online and connected. People can have, seek, decide and other things related to their lives. In other words there are only limited to the touch of their fingers and the internet. This is not difficult to prove; in 2015, more than 4 billion people in the world had access to the internet (Internet World Stats, 2019). The growth of the digital era is directly proportional to the development of the information technology industry. This is relating each because the information technology industry is a major factor of the digital era that acts as a provider. For example, two years ago, if we wanted to buy daily necessities like food, we had to go to the market. However, many e-commerce centers provide food nowadays and we only order and wait until the product will arrive at the customer. This shows the supporting role of the information technology industry as a provider in the digital era.

The rapid development in the technology industry must certainly balance with the quality of its human resources, so as to produce a positive output. Diverse market needs require diverse results, which can be pursuing by combining ideas from the diversity of a company's workforce. Diversity were recognized to exist within an organization when its members differ from each other (Thomas and Ely, in (R. Rao \& Bagali, 2014) In business terms, diversity defined as differences in 
individual traits including socio-demographic variables and professional variables. The main dimensions of diversity include age, ethnicity, gender, race, religion, and disability (Das, and Wagar, 2007). Most multinational companies in the information technology industry and other companies have consciously practiced diversity and benefited, (R. Rao, et al., 2014) in Bagali et al, 2014). Organizations that have a significant diversity ratio have a better understanding of international markets that can make a profit (bedi, lakra, \& Gupta, 2014). This is also supported by Dobbs in Bagali (2014) which states that many companies have found an increase in workforce diversity which is directly proportional in terms of performance improvement, happier customers and more satisfied employees (Dobbs in Bagali, 2014). But on the other hand, diversity can bring its own challenges. Personal thoughts, likes \& dislikes, gender views, ethnic backgrounds cause discrimination, prejudice, and ethnocentrism, which in turn create barriers in promoting diversityfriendly cultures in ecosystems (Singh, Winkel, \& Selvarajan, 2013). This condition also supported with the frequent diversity management programs that not seriously taken by the company. The issue of gender diversity considers being a very important issue highlighted especially gendering discrimination or gender disparity. Lawsuits to Morgan Stanley who had to pay \$54 million for gender discrimination show that gender issues should be taken seriously. Globally, the world of information technology is known to be synonymous with the world of "men". Facebook, Google, Twitter, Yahoo, Amazon, Snapchat, Alibaba, Tokopedia, Bukalapak founders are male. In terms of hardware and operating systems, men also founded Apple and Microsoft. This stereotype develops among the people including Indonesia which more or less influences women's career choices in the information technology industry. Meanwhile, a study from the Peterson Institute in 2016 showed that of 21,980 companies in 91 countries, many female leadership in company management resulted in an annual profit increase of $2.7 \%$ higher than those who did not. According to Bagali (2014), women represent the main economic power in most developing countries. With a balanced gender comparison in the upper management ranks, women's participation can provide diversity of ideas and views in business. Therefore, if there is an imbalance in the gender ratio in a busy industry according to the era, it will definitely affect the economy and social. Indonesia is a developing country but based on the World Economics Forum index, Indonesia is ranked $10^{\text {th }}$ country with the Gender Gap Index. Indonesia is the fifth largest start-up country in the world. Based on the Startup Ranking as of March 21, 2019, the number of startups owned by Indonesia reached 2,074. According to data held by iPrice Group in the technology industry or e-commerce category, only $21 \%$ of women occupy the position of president director or the highest level in company management. women and men in Indonesia is still a challenge; this revealed by the composition of the mapping made by the Indonesian Creative Industries and Information Technology (MIKTI) with BeKraf. Based on data from the report, it appears that men $(91.18 \%)$ established the majority of start-up companies in Indonesia, while women only accounted for $8.82 \%$ of the total founding founders. One of it causes the decreasing number, on the other hand is the stereotype that causes the low participation of women in science and technology. Increasing diversity among employees in the information technology industry is a reflection of improving educational facilities and increasing levels of community education in developing countries, social change, social shifts from various regional groups, then career orientation among women, increasing aspirations for work and career, (Bagali, 2014). This makes companies engaged in the information technology industry must be aware of the issue of gender diversity, they must be able to equalize gender disparities at various levels because diversity that managed well could bring benefits to companies. Therefore, based on the existing background the writer is interested in discussing "Women's Equality in the E-Commerce Information Technology Industry in the Digital Era in Developing Countries". The research will conducted with the aim to find out the real conditions and roles of women, which have been and filled by women, women's 
equality and supporting and inhibiting factors in terms of career equality in Indonesia's ecommerce information technology industry.

\section{A Literature Review Gender's Diversity on Information Technology Term}

According to WHO gender defined as a set of roles, behaviors, activities, and attributes that are consider appropriate for men and women who are socially constructed in a society. Diversification of the structure of human resources related to gender mix often seen as important for maximizing important company resources (Sicilian in Armas, 2016). McKinsey \& Company revealed that companies that are committed to leadership that pay attention to diversity would be more successful, organizational and financial. Because diversity will improve employee talent, customer orientation, increased sales, profits and decision-making, (Herring, 2009). Gender diversity also in the position of the executive board also reduces volatility and improves balance during the economic cycle, (Rohner and Dougan, 2012).

In the information technology industry that is dynamic, moves fast and meets the needs of many people from different backgrounds, diversity needed to keep pace with its movement. Gender diversity that can provide diverse talent and abilities within a company needed to be able to optimize and enhance company innovation, (Bagali, 2014). Ideas that collected only from one gender will become monotonous. This is in line with Doz, et al (2004) which states that innovation changes are difficult to obtain from groups whose knowledge base is homogeneous. Heterogeneous sources of ideas will create high product or service accuracy because they are able to see from a variety of perspectives.

(Kundu \& Mor, 2017), prove that gender diversity affects company performance. Especially for entrepreneurs, financial performance is crucial. Gender diversity also influences financial performance. These include, among other things, patent results (Chen et al, 2015), and reducing fraud (Cumming, Leung, \& Rui, 2015) . Gender diversity can also control team productivity so that it is on time and the cost does not exceed the budget.

\section{Women on The Information Technology Industry}

According to Hou, (2014) online media have not touched the balance between men and women in accessing technology. Indonesia has a female population that is still below men but with a figure that is not too far away, but the percentage of gender gap in technology is still greater than the percentage ratio of population based on gender. This is supported by data owned by the Indonesian Information and Communication Technology Creative Industry Society or Masyarakat Industri Kreatif Teknologi Informasi dan Komunikasi Indonesia (MIKTI) together with BeKraf, it appears that the majority of start-up companies in Indonesia were founded by men $(91.18 \%)$, while women only accounted for $8.82 \%$ of the total founding. According to Hilbert (2011), there is a tendency for women to experience technophobia compared to men. Existing stereotypes also help shape this phobia pattern. One of the stereotypes in Indonesia related to the role of women in the world of work, women still portrayed as being gentle and unable to handle the various roles and tasks that have been dominated by men. Gender stereotypes about the information technology industry also create the myth that men are better at dealing with "hardware" technological problems that require logic and mathematical concepts. This stereotype assumes that women are better at human skills about "nurturing, emotional expression, and communication activities" while men are better at "instrumental and task-oriented jobs" (Widjajani, 2013). 
Taken from Business Insider Singapore, shows that men occupy $65 \%$ of management positions in the e-commerce industry and the rest are only filling by women. In the head-level position, the number of women is almost equivalent to men, which is $55 \%$ for men and $45 \%$ for women. In the VP-level position, the number of men is $61 \%$, while women must be satisfied with the number of $39 \%$. The higher the level, the further the woman lags, conical upwards. In SVP-level, men reach $80 \%$ and women occupy the rest. Then in the C-level position which becomes the top position in a company, women only reach $17 \%$ and men so dominate up to $83 \%$. In addition there is a description of the way women work as dualism: home vs. work, IT vs. work emotion, intuition vs. analysis, and so on (Nielsen in (Widjajani, 2013). These stereotypes because the hierarchical structure in the IT world to be dominating by men at the top level, while women occupy low-level positions.

Indonesia also experienced the same thing. Nearly half of Indonesia's population is female, but only $5-10 \%$ of the highest management positions held by women. The issues also made Indonesia occupy 88th position out of 144 countries in the world for gender equality in 2016. The World Economics Forum also revealed Indonesia was ranked 10th in the Gender Gap Index in Southeast Asia. In a developing country, the differences of access together with factors such as inequality in professional education and training, access to finance, holding assets, and others lead to a digital gender divide, limiting the transformational effects created by digital technology. Women usually employed at the end of the value chain or work chain (Sinha, 2018).

From an economic standpoint, Bagali (2014) revealed, women have the main economic strength in most developing countries. Women have the talent to attract and maintain naturally. Women pay greater attention in managing companies. According (Sari Kusumastuti, Supatmi Supatmi, \& Perdana Sastra, 2007), women have a very high attitude of prudence, tend to avoid risk, and more conscientious than men. This side makes women not in a hurry in making decisions. For this reason, having women in a company can help make more informed decisions and lower risk. This makes women the subject of strategic discussion in organizations. Fathonah, (2018) revealed that the composition of women in the company had a significant effect on the company's current ratio. The same thing was also stated by McKinsey \& Company, Rohner and Dougan, (2012) which showed a large return on return on equity, price or equity ratio, earnings before taxes, stock price growth and average growth obtained from observing diversity gender.

\section{Women's Equality in Information Technology Industry}

When the economy increasingly driven by information technology and the current digital economy believed to change the way people work and world civilization in the future, this gender gap problem must addressed appropriately. The superiority of workforce diversity has been a debate throughout the world. Diversity management has carried out and noticed by companies in order to develop a workforce that can compete globally and grow fast. The need for a mix of talents to create innovation and creativity pressures entrepreneurs in the information technology industry to attract and retain a diverse workforce. Entrepreneurs urged to embrace gender diversity and advised not to ignore it to avoid the risk of losing competitive advantage.

Therefore, managing gender diversity can be done with gender equality. Gender equality between men and women, is a concept that states that all humans, both men and women, are free to develop their personal abilities and make choices without limiting stereotypes, rigid gender roles and prejudice (Widjajani, 2013). Gender equality means that differences in the behavior, aspirations and needs of women and men considered, valued and recognized equally. On the other hand, workers' perceptions and attitudes towards diversity issues also become an important component in achieving success (Eramus in Veldsman, 2013). Nevertheless, the company should 
manage all that. Lehman, (2008) suggests that gender-balanced teams are most likely to experiment, be creative, share knowledge, and fulfill tasks.

Woolley et al. (2010) found a relation between the proportion of women and higher collective intelligence, defined as "the general ability of a group to perform various tasks". The structure of the female brain can work simultaneously on the right and on the left, which can support multitasking to work on or focus on several things at once. They also found that the team's collective intelligence increased with the number of women in the group, perhaps because of the higher performance of women on tasks that required social sensitivity. This statement further supports that women should given the same opportunities as men in their careers, especially in the "man dominated" sectors. Hoogendoorn et al, (2013) stated that a gender-balanced team would defeat a team that dominated only by men and teams that were dominated by women.

\section{E-Commerce}

All aspects of life in the world are increasingly required to be faster and more efficient. One of them is to meet the needs, and as time evolves, it is formed how to shop without spending more effort and time, e-commerce. Understanding the concept of e-commerce is a trading procedure or mechanism of buying and selling on the internet where buyers and sellers brought together in cyberspace. e-Commerce can also be defined as a way of shopping or trading online or direct selling that utilizes Internet facilities where there are websites that can provide "get and deliver" services. According to Wong (2010), e-commerce is the buying, selling and marketing of goods and services through an electronic system. Like radio, television and computer networks or the internet. Therefore, the notion of e-commerce is the process of buying and selling transactions carried out through the internet where the website used as a container to carry out the process.

\section{Research Method}

The method used in writing this article is literature review. This method is a search of literature both internationally and nationally conducted using journals, articles, data websites and online research in the fields of economics and business. The search carried out using keywords diversity, gender, women's equality, IT industry and related matters. The type of data used is secondary data type, because the data collected is not directly in the actual sight. The analysis used in the literature review is qualitative.

The discussion on gender equality as managing diversity in this review literature covers analysis of Indonesia and the e-commerce information technology industry, conditions and management of women's equality and the supporting and inhibiting factors that exist. 


\section{Result and Discussion}

\section{Indonesia and the E-Commerce Information Technology Industry}

Indonesia is a developing country and has the number four population density in the world. The population in Indonesia reaches 267 million divided by sex, consisting of 134 million men and 133 million women. Indonesia is currently enjoying a demographic bonus period where the population of productive age is more than the unproductive age, which is more than $68 \%$ of the total population. (katadata.co.id), this must be well utilized to advance Indonesia and make the most of the latest revolutionary moment, 4.0. The information technology industry plays an important role in placing a country on the global map. One of the steps and focus of Indonesia is on e-commerce. Indonesia has the advantage that is, the costs required to do business are lower when compared to many other countries, but the results that will obtained are not low. In addition, Google Temasek data also revealed that Indonesia is a mobile-first country where more than $94 \%$ of people are connected and access the internet through smartphone devices. The average community spends 4 hours accessing the internet through mobile devices. In fact, $68 \%$ of the connected people are online shopper, who use mobile / smartphone devices to find the desired product. Both of these can be used as reasons that Indonesia is the best place to start an e-commerce business

Indonesia leads the value of e-commerce transactions in the Southeast Asian region driven by 150 million internet users and the growth of smartphone users (katadata.co.id). E-commerce has become the most dynamic sector of the internet economy in the Southeast Asian region. The government, in this case the Ministry of Industry, has shown its seriousness in supporting ecommerce in Indonesia. The government began to facilitate the logistics process, ease of import, and financing. Harmonization of regulations is also carried out, including taxation, excise, payment gateway, so that local products can be circulated in the ASEAN market.

In the ASEAN region, Indonesia leads the value of e-commerce transactions with a value of US $\$ 1.7$ billion in 2015. The value will surge 94\% (Compound Annual Growth Rate / CAGR) to US \$ 12.2 billion in 2018. By 2025, will jumped $41 \%$ to US \$ 53 billion and remains a leader in ASEAN (google temasek, 2018). Three e-commerce startups that have now become unicorns, namely Lazada, Shopee and Tokopedia have played an important role in the development of ecommerce in Southeast Asia. By offering tens of millions of products, the experience of shopping by using a cell phone, discount promos, and an extensive logistics network makes them a driving force for the growth of electronic commerce in Southeast Asia.

In addition, the rapid growth of the existing information technology industry evidenced by the status of Indonesia that is the country with the fifth largest start-up in the world. Startup ranking as of March 21, 2019, said the number of startups owned by Indonesia reached 2,074. A number of startups or technology start-ups have sped and developed not only in terms of market share, but also in terms of valuations (tirto.id). Bank Indonesia indeed records the number of electronic money transactions in Indonesia continues to increase. In 2011, the nominal value of electronic money transactions reached Rp981 billion then in 2017 the amount reached Rp12.375 trilyun. In the third quarter of 2018, this amount increased to Rp31.6 trilyun. So, from the point of view of the government, it can project that Indonesia will become the largest digital economy country in Southeast Asia in 2020 by targeting 1,000 technopreneurs with a business valuation of USD100 billion and a total e-commerce value of USD130 billion (kemenperin.go.id). Today's digital economy believed to change the way people work and world civilization in the future, e-commerce is one of them. 


\section{Riil Condition of Women in Indonesia's E-Commerce}

It is undeniable that in e-commerce some of the consumers are women. The tendency of women shopping hobbies is a target for e-commerce players. According to Snapcart in 2018, Indonesia has e-commerce consumers with a female gender reaching $65 \%$. Even though women are potential target consumers, there are things that block, namely, managerial positions that in fact make important decisions in e-commerce business strategies dominated by men. In addition Bank Indonesia data for 2018 shows that $60 \%$ of women are MSME owners. However, not all MSMEs utilize e-commerce. This shows that women are also targets for e-commerce from the seller's point of view to collaborate, because in this 4.0 era everything integrated.

Existing conditions should be a strong basis for e-commerce businesses to provide women's space in the ranks of management. Women's participation can provide diversity of ideas and views in business. Women's ideas and aspirations will become more valuable because consumers and prospective sellers, the majority of whom are women from various aspects and layers, had better understand them. The Peterson Institute study suggests that at least three women participate in management to optimize business potential significantly. According to iPrice, the lack of women's participation can still be found especially in the ranks of company management. Overall, women's participation in managerial positions is still far below that of men, which is only $31 \%$. Then, the gap in the workforce of women is getting bigger at a higher career level (President Director and Director). If distinguished by career level, the gap will be increasingly visible, namely only $21 \%$ of women occupy the position of President Director or the highest level in company management. At the Director level, the portion of women also has not improved with the same percentage of $21 \%$. At the Division Head level, women's participation seems to have improved slightly with a percentage of $36 \%$. However, this figure has not approached an equal comparison between the two genders in the company's management. The same thing also revealed by katadata, the gap is very visible from the side of startup founders, where $91.18 \%$ of the founders are male; the remaining $8.82 \%$ is female.

Women are the main economic power (Bagali, 2014). This can be reflected in the findings of McKinsey \& Company, Rohner and Dougan, (2012) which show a large return on return on equity, price / equity ratio, earnings before taxes, stock price growth and average growth obtained from paying attention to gender diversity especially the role of women. More specifically at the career level, Krishnan et al. (2005) analyzed the gender composition in the top management team and found a positive relationship between the higher proportion of women and the company's return on assets. Therefore, in general, the involvement of women at the top level will bring financial benefits to the company. This condition shows that it is very important to equalize women with their capacity and expertise. Women must be accepted, seen and given equal career paths up to the top level of management. Equality is also a matter of influence in line with research by Hoogendoorn et al. (2013) which states that a gender-balanced team will defeat a team that dominated by men and teams that dominated by women. Equivalent number of women at the top level of management will make the team more dynamic and productive, because it is not monotonous.

\section{Women's Equality Influence Factors}

The influence factors in women's equality divided into two parts, namely, internal and external. Internal factors such as psychological factors such as education, interests, motivation and personality such as tenacity, patience and women also rely on positive emotions at work. 
(Woolley, Chabris, Pentland, Hashmi, \& Malone, 2010) found that the team's collective intelligence increased with the number of women in the group, perhaps because of the higher performance of women on tasks that needed social sensitivty. Therefore, the emotions that women have at work are more beneficial when compared to men. External supporting factors in women's equality can include their family, surrounding environment, and workplace. The intended workplace support is an equal opportunity between women and men to achieve the highest career by looking at their capabilities, and proper management of existing gender diversity.

\section{Women's Equality Inhibiting Factors}

Factors inhibiting women's equality according to Widjajani (2013) grouped into several parts, namely psychic, work-life balance, and gender discrimination. Psychic factors can be both supportive and inhibiting for women. If women workers use emotions and feelings too much, it will be difficult to adapt, and easily discouraged will hamper their own career development. Factors of self-confidence also make it still very few women occupy strategic positions in companies. This has indirectly formed from their mindset because of the existing stereotypes. In accordance with (Hilbert, 2011), which states that there is a tendency for women to experience technophobia compared to men? Existing stereotypes also shape the mindset of men who will influence the tendency of gender discrimination.

Work-life balance is usually for women who are married and have children. Jobs that are dynamic, tend to require long work time, and are available at any time can be an obstacle for women because the focus is fragmented. According to Widjajani's research, (2013) found $47 \%$ of women want to get out of the information technology industry because of their fear of not being able to run the right work-life balance.

\section{Women's Equality Consistency}

Equality of women in working in Indonesia's e-commerce business can be start by trying to shift the existing stereotypes both from the point of view of women and men. This growing stereotype causes job opportunities for women in this world to be limited. This is the most basic thing, because after all the mindset that we have will affect things around us. If our mindset believes in existing stereotypes, then the way we see, treat, and trust will not separated from the existing stereotypes. One-step that can be taking is to establish associations or movements that have a vision of introducing the world of information technology and helping support women with each other and being able to demonstrate equality in men, who adapt the mentoring method. Furthermore, involving men deemed necessary in this regard.

Generation Girl is the real example from the non-profit institution. Several young women in the technology industry founded this collective. Crystal Widjaja, Mila Alfitri, and Anbita Nadine Siregar from Go-Jek. Josephine Bahari from Blueboots Farm, Janice Widjaja from Moka Pos. In addition, there is also a figure named Fadri Attamimi. Generation Girl provides choices for Indonesian women in determining their career choices. Women can have a career not limited to office employees, doctors, and accountants, but rather as a developer and programmer of the information technology industry. This institution also gives an understanding that in the technology industry, moreover becoming a programmer and developer gives work flexibility by working remotely, so that it is not necessary to be present every day in the office. Lisa Widodo as senior vice president of operations and product at Blibli.com, can be used as an example that the status of being married and having children does not become a burden for her career in e- 
commerce. Sinha, (2018), states that women themselves must have awareness to take advantage of opportunities.

However, it cannot deny that women who work and have children have different levels of burden. Widjajani, (2013) revealed that 54\% of women want to leave their jobs in high-level positions because they are married. Sponsorship in the work environment can be the solution, and can equalize the level of women. We know that working with children will burden your mind if you have to leave it at home with a caregiver. The company must provide sponsorship for this problem. Sponsorship i carried out by providing day care. International Finance Corporation in 2017 stated that companies that offer childcare services provide greater opportunities for women to occupy leadership positions and increase productivity in the company. The higher position of women, the higher the income. More productive of the employee the more profitable the company. The higher profit of a company, the greater its influence on the economy. In line with the Bagali phrase (2014) that women have major economic power in most developing countries. Indonesia is a developing country with promising e-commerce sector so children's day care sponsorship of ecommerce companies with offices in Indonesia must considered.

Korn Ferry stated that men earned an average salary $16.1 \%$ higher than women did, globally. The problem of salary differences between men and women is not because women and men do not get the proper salary in the same job position, but rather are more likely to have labor imbalances. One factor influencing this is that more men are in senior management positions in the sector and higher-paid job functions, while women are more in lower employment positions in the company. This gap can eliminate if companies continue to try to increase the percentage of women in the best-paid labor market, including roles and functions in top-level management because they have the right skills and competencies. According Kusumatuti et al (2007), women have a very high attitude of prudence, tend to avoid risk, and more conscientious than men. This side makes women not in a hurry in making decisions. For this reason, having a woman in a company can help make more appropriate decisions and lower risk that must be appreciated with an equal salary.

In addition, women's unequal equality caused by discriminatory recruitment and selection such as job advertisements that mention "vacancies for men". According to Mardianto in Widjajani, (2013) this is a violation, because according to the laws / government regulations that men and women have equal employment opportunities. The practice of full recruitment in this industry must be based on their expertise and abilities, not by differentiating - gender difference. On the other hand, women must be motivated to fulfill actualization to be more productive and able to achieve. Actualization needs include: the desire to demand things that are satisfying needs in order to be able to realize their potential, get the opportunity to take part in responsibility for a job, involve in proposing problem solving or decision making, the possibility for personal growth, development and progress, enhance status and gain recognition and demonstrate ability and self potential.

\section{Acknowledgement}

Indonesia is a developing country that still has a high enough labor gap. The status of Indonesia, which built as a strong leader in the world of e-commerce in Southeast Asia in 2025, must be a strong motivation in equalizing women in the world of e-commerce. Women and the world of e-commerce have strong ties, both in terms of buyers and sellers. The role of women as the driving force of e-commerce in Indonesia is very strong. However, stereotypes in Indonesia are also strong in influencing women's trust and equality. This literature review found women's equality to hamper by psychological factors, work-life balance and gender discrimination. Peer support such as the non-profit movement can be a solution to motivate and educate Indonesian 
women. Then, day care sponsorship for children can also be a solution for Indonesian professionals, because not a few Indonesian women who give up their careers after having children. The recruitment process must consider, based only on the expertise and abilities of women.

\section{References}

Armas, Sandro. (2016). Pengaruh diversitas gender, remunerasi direksi, dan struktur kepemilikan terhadap kinerja perusahaan. Skripsi. Universitas Lampung.

Bedi, P., lakra, P., \& Gupta, E. (2014). Workforce Diversity Management: Biggest Challenge Or Opportunity For 21st Century Organizations. IOSR Journal of Business and Management.

Chen, J., Leung, W.S., and Evans, K.P., 2015. "Board Gender Diversity, Innovation and Firm Performance" Working Paper, Available at SSRN: https://ssrn.com/abstract=2607295

Cumming, D., Leung, T. Y., \& Rui, O. (2015). Gender diversity and securities fraud. Academy of Management Journal.

Doz, Y., Santos, J., \& Williamson, P. (2004). Diversity: The key to innovation advantage. European Business Forum, 17, 26.

Fathonah, Andina Nur. (2018). Pengaruh Gender Diversity dan Age Diversity Terhadap Kinerja Keuangan. Jurnal Riset Akuntansi dan Keuangan Program Studi Akuntansi. Fakultas Pendidikan Ekonomi dan Bisnis. Universitas Pendidikan Indonesia, 6(3), 373-380.

Herring, C. (2009). Does diversity pay?: Race, gender, and the business case for diversity. American Sociological Review.

Hilbert, M. (2011). Digital gender divide or technologically empowered women in developing countries? A typical case of lies, damned lies, and statistics. Women's Studies International Forum.

Hoogendoorn, S., Oosterbeek, H., \& Praag, M. van. (2013). The impact of gender diversity on the performance of business teams: Evidence from a field experiment. Management Science, 59(7).

Hou, Jianwei. (2014). On Line stock trading: Do Demographics, Internet Usage, and Attiudes Matter?. Minnesota State University Mankato. Amerika Serikat.

Krishnan, H. A., \& Park, D. (2005). A few good women--On top management teams. Journal of Business Research, 58(12), 1712-1720.

Kundu, S. C., \& Mor, A. (2017). Workforce diversity and organizational performance: a study of IT industry in India. Employee Relations.

McKinsey \& Company. (2007). Women matter: Gender diversity, a corporate business driver, 1214. 
McKinsey \& Company. (2015). Does Diversity Matters?, 1-3.

R. Rao, S., \& Bagali, D. M. M. (2014). Workforce diversity and management: An emphirical study on relationship between diversity management practices, obstacles and acceptance of gender diversity among employees in IT industry; Bangalore. IOSR Journal of Business and Management.

Sari Kusumastuti, Supatmi Supatmi, \& Perdana Sastra. (2007). PENGARUH BOARD DIVERSITY TERHADAP NILAI PERUSAHAAN DALAM PERSPEKTIF CORPORATE GOVERNANCE. Jurnal Akuntansi Dan Keuangan.

Singh, B., Winkel, D. E., \& Selvarajan, T. T. (2013). Managing diversity at work: Does psychological safety hold the key to racial differences in employee performance? Journal of Occupational and Organizational Psychology.

Sinha, S. (2018). Gender digital divide in India: Impacting women's participation in the labour market. In Reflecting on India's Development: Employment, Skill and Health.

Veldsman, D.M. (2013), "Perceptions of diversity management in a public sector organization/ government institution within the Western Cape", unpublished doctoral dissertation, University of Western Cape, Cape Town.

Widjajani, S. (2013). Kajian Eksistensi Wanita Indonesia Di Bidang Teknologi Informasi Untuk Mendorong Tercapainya Kesetaraan Jender Dalam Karir. Jurnal Manajemen Informatika, 2(1), 23-32.

Woolley, A. W., Chabris, C. F., Pentland, A., Hashmi, N., \& Malone, T. W. (2010). Evidence for a collective intelligence factor in the performance of human groups. Science.

Wong, Jony. (2010). Internet Marketing for Beginners. PT Elex Media Komputindo. Jakarta. https://www.internetworldstats.com/stats.htm

https://iprice.co.id/trend/insights/kesetaraan-gender-tenaga-kerja-indonesia/

https://databoks.katadata.co.id/datapublish/2019/03/14/pendiri-startup-di-indonesia-masih-didominasi-pria

https://www.kornferry.com/press/korn-ferry-global-gender-pay-index-analyzes-reasons-behind-inequalitiesin-male-and-female-pay

https://ifcextapps.ifc.org/ifcext\%5Cpressroom\%5Cifcpressroom.nsf\%5C0\%5C8419D639F1154703852581A 900594D9F

https://piie.com/publications/workingpapers/gender-diversity-profitable-evidence-global-survey 
